\title{
ADHERENCE TO LIFESTYLE RECOMMENDATIONS OF THE WORLD CANCER RESEARCH FUND/AMERICAN INSTITUTE FOR CANCER RESEARCH OF BREAST CANCER SURVIVORS ON ADJUVANT HORMONE THERAPY AND ASSOCIATED FACTORS
}

\author{
ADESÃO ÀS RECOMENDAÇÕES DE ESTILO DE VIDA DO WORLD CANCER \\ RESEARCH FUND/AMERICAN INSTITUTE FOR CANCER RESEARCH DE \\ SOBREVIVENTES AO CÂNCER DE MAMA EM TERAPIA HORMONAL \\ ADJUVANTE E FATORES ASSOCIADOS
}

\author{
Luísa Comerlato Jardim ${ }^{1}$, Priscila da Trindade Flores ${ }^{2}$, \\ Maria do Carmo dos Santos Araújo ${ }^{3}$, Juarez Chiesa, Clandio Marques ${ }^{3}$, \\ Raquel Pippi Antoniazzi ${ }^{4}$ e Cristina Machado Bragança de Moraes $^{5}$
}

\begin{abstract}
About $30 \%$ to $40 \%$ of cancers can be prevented through healthy diet, adequate body weight and regular physical activity. The adherence to lifestyle recommendations of the World Cancer Research Fund/American Institute for Cancer Research (WCRF/AICR) has been associated with lower risk of death in cancer survivors. The objective of this study was to evaluate adherence to the new recommendations of the WCRF/AICR by Brazilian women in adjuvant hormone therapy for breast cancer and its associated factors. This cross-sectional study was carried out from January to August 2017, in Santa Maria, RS. Regarding the recommendations of the WCRF/AICR the average adherence score was 4.4 points out of a total of 8 points. Higher adherence is associated with higher schooling. In individual recommendations, physical activity showed the lowest adherence whereas alcohol consumption showed the highest adherence. The data suggest that Brazilian breast cancer survivors, especially those with lower levels of education, could benefit from dietary counseling and physical activity.
\end{abstract}

Keywords: breast neoplasm, survivors, body weight, life style.

\section{RESUMO}

Cerca de 30\% a 40\% dos cânceres podem ser evitados através de dieta saudável, peso corporal adequado e atividade física regular. A adesão às recomendações de estilo de vida do World Cancer Research Fund/ American Institute for Cancer Research (WCRF/AICR) têm sido associadas ao menor risco de morte em sobreviventes do câncer. O objetivo desse estudo foi avaliar a adesão às novas recomendações do WCRF/AICR, por mulheres brasileiras em terapia hormonal adjuvante para o câncer de mama e os seus fatores associados. Este estudo transversal foi desenvolvido no periodo de janeiro a agosto de 2017, em Santa Maria, RS. O escore médio de adesão às recomendações da WCRF/AICR foi de 4,4 pontos, de um total de 8 pontos. A maior adesão está associada à maior escolaridade. Nas recomendações individuais, a menor adesão foi para ati-

1 Docente do Curso de Odontologia - UFN. E-mail: luisacomerlato@hotmail.com

2 Mestre em Ciências da Saúde e da Vida - Universidade Franciscana - UFN. E-mail: priscilatfores@hotmail.com; luisacomerlato@hotmail.com

3 Colaboradores - Hospital Universitário de Santa Maria. E-mail: mcgabb@gmail.com; juarezchiesa@brturbo.com.br 4 Colaboradora - Universidade Federal de Santa Maria - UFSM. E-mail: raquelantoniazzi@hotmail.com

5 Docente do Mestrado de Ciências de Saúde e da Vida- Universidade Franciscana - UFN. E-mail: c_bmoraes@yahoo.com.br 
vidade física e o consumo de álcool apresentou a maior adesão. Os dados sugerem que sobreviventes brasileiras do câncer de mama, sobretudo as de menor escolaridade, poderiam ser beneficiadas através do aconselhamento dietético e da atividade física.

Palavras-chave: neoplasia de mama, dieta, peso corporal.

\section{INTRODUCTION}

The World Cancer Research Fund (WCRF)/American Institute for Cancer Research (AICR) estimates that about $30 \%$ to $40 \%$ of cancers can be prevented through healthy diet, adequate body weight and regular physical activity. These factors are attributed to the most common causes of cancer, after smoking (WCRF/AICR, 2007). There is evidence that body fat accumulation and weight gain are strong causes of many types of cancers, and have increased significantly over the last decade (WCRF/AICRa, 2018). Increased physical activity and a healthy diet after diagnosis have been associated with reduced risk of cancer recurrence and mortality, improved quality of life and treatment tolerance (IRWIN; MAYNE, 2008; FERRINI; GHELFI; MANNUCCI, 2015).

As the diagnosis and treatments for breast cancer $(\mathrm{BC})$ evolve, more women are surviving and for longer periods (AMERICAN INSTITUTE FOR CANCER RESEARCH, 2018). In Brazil, approximately $87 \%$ of people diagnosed with BC survive five years after diagnosis(WCRF/AICRb, 2018).

During survival, it is recommended that patients follow the same lifestyle guidelines used for cancer prevention (WCRF/AICR, 2007; WCRF/AICRa, 2018). In 2007, the WCRF, in collaboration with the AICR, formulated eight recommendations for cancer prevention(WCRF/AICR, 2007). Adherence to these recommendations has been associated with a lower risk of developing the disease, especially BC (FANADI et al., 2015; ROMAGUERA et al., 2012). For survivors, adherence to the WCRF/AICR recommendations is associated with a lower risk of death (INOUE-CHOI; ROBIEN; LAZOVICH, 2013). Experts have recently published the third report that brings together the latest research and evidence on cancer prevention and survival through diet, nutrition, and physical activity (WCRF/AICRa, 2018). In this context, it is necessary to know the social and environmental factors that influence the diet and physical activity patterns in different populations with cancer (MAKAREM et al., 2015).

This study aimed to evaluate adherence to the new WCRF/AICR lifestyle recommendations by Brazilian women in hormonal adjuvant therapy for BC and its associated factors.

\section{METHODS}

\section{CHARACTERIZATION OF THE POPULATION AND DESIGN}

The population of this cross-sectional study was selected from a sample of patients attending at Public School Hospital located in the central region at southern Brazil between January and 
August 2017. The evaluations were performed in the waiting room of the outpatient clinic during the quarterly consultations. The study included women in adjuvant hormone therapy (HT) who were over 18 years of age and who agreed to participate in all stages of the evaluation. Patients who were not submitted to the anthropometric evaluation were excluded from the study. The present study was approved by the Committee of Ethics in Research with Human Beings of the Franciscan University under the number 62708516.6.0000.5306.

\section{DATA COLLECTION}

The sociodemographic data collection was performed by previously trained health professionals, using a questionnaire developed for the study. Clinical data were collected directly from the medical records of the patients.

The type, frequency and duration of the physical activities were evaluated through a structured interview. The social classes were categorized according to the minimum wage (MW), as established by the Brazilian Institute of Geography and Statistics (IBGE): Class A (more than $15 \mathrm{MW}$ ), Class B (05-15 MW); Class C (03-05 MW), Class D (01-03 MW), Class E (01 MW). The reference MW was R \$ 937.00. It was classified as domestic occupation (homeworkers and retirees) and external occupation (women active in the labor market). Weight and height were measured using standardized procedures and used to calculate BMI, according to the World Health Organization(1995).

Food consumption was evaluated through a quantitative Food Frequency Questionnaire, validated for the Brazilian adult population (RIBEIRO; OLIVEIRA; RODRIGUES, 2006). To obtain total fiber and calorie consumption, the records were calculated using the software Dietwin ${ }^{\circledR}$.

\section{ADHERENCE SCORES}

Adherence to the WCRF/AICR recommendations of 2018 (WCRF/AICRb, 2018) were determined using the scoring and classification methodology of Romaguera et al (2012). For each recommendation met, 1 point was assigned; for recommendations that were partially met, 0.5 points were assigned and, if not met, 0 points. The total score of the present study ranged from 0 to 8 and was categorized by the tertiles of the sample. The individuals who scored higher were the same individuals who showed greater adherence to lifestyle recommendations for cancer prevention and survival. The operationalization of the recommendations is outlined in Table 3.

The recommendation of consumption of "fast foods" was evaluated by the energy density of the diet. They have been deemed to be convenience foods readily available, which tend to be energy dense and are often consumed in large portions (WCRF/AICRc, 2018). Diets higher than $>125 \mathrm{Kcal} / 100 \mathrm{~g}$ are considered to be of high energy density (WCRF/AICR, 2007). The recommendation 
for the use of dietary supplements was excluded, as the determination for the use or not of supplements was not evaluated.

\section{STATISTICAL ANALYSIS}

Continuous data were described as mean and standard deviation, categorical variables were presented in absolute and relative frequencies. The normality distribution was assessed by the Shapiro-Wilk test. Data associations between groups were performed using the chi-square and Mann-Whitney tests. All the analyzes of the study were performed in SPSS 22.0 (Statistical Package for the Social Sciences, SPSS, Chicago, USA) and values of $\mathrm{P}<0.05$ were considered significant.

\section{RESULTS}

The sample consisted of a total of 150 women who survived BC, in adjuvant hormone therapy. The average adherence score was 4.4, out of a total of 8 points. The score ranged from 2 to 7.5 points.

A total of 65 participants $(43,2 \%)$ had an adherence score between 0 and 4 points; 48 participants (32\%) scored between 4.5 and 5 and 37 participants (24,7\%) scored more than five points (Table 1). The mean age of participants was $56.76 \pm 11.09$ years, $7.36 \pm 4.04$ years of study, higher prevalence of economic class D (48,7\%), white race (77,3\%), married (62\%), internal occupation (52\%) and nonsmokers (69,3\%). Table 1 also shows that the sociodemographic variables, except for schooling, were not significantly associated with the level of adherence. The mean years of study were significantly higher in women who had more adherence to recommendations $(p=0.020)$.

Regarding the clinical variables presented in table 2 , the time of treatment of hormone therapy was $28.86 \pm 20.93$ months and the time of diagnosis of breast cancer was $38.06 \pm 20.06$ months. The drug most commonly used was tamoxifen (96\%), the majority $(50,7 \%)$ underwent non-conservative surgery in the breast, and most of the women assessed (80,4\%) were in stages I and II. 56,7\% of the women underwent previous treatments of chemotherapy and $66 \%$ underwent treatments of radiotherapy. $79,3 \%$ entered the menopause naturally and the majority (68,7\%) presented none or only 01 associated diseases. None of the clinical variables was associated with the classification of the level of adherence. 
Table 1 - Sociodemographic characteristics according to the classification of adherence to the recommendations of the WCRF/AICR, of survivors of breast cancer in adjuvant hormone therapy, Central Region, RS, 2017.

\begin{tabular}{|c|c|c|c|c|c|}
\hline \multicolumn{6}{|c|}{ Adherence score } \\
\hline \multirow{3}{*}{ Variables } & $0-4$ & $>4-5$ & $>5$ & & Total \\
\hline & $\mathrm{N}=65$ & $\mathrm{~N}=48$ & $\mathrm{~N}=37$ & $\mathbf{p}$ & \\
\hline & mean $\pm \mathrm{DP}$ & mean $\pm \mathrm{DP}$ & mean $\pm \mathrm{DP}$ & & mean $\pm \mathrm{DP}$ \\
\hline Age (years) & $57,36 \pm 12,14$ & $55,62 \pm 10,22$ & $57,18 \pm 10,39$ & 0,667 & $56,76 \pm 11,09$ \\
\hline \multirow[t]{2}{*}{ Schooling (years) } & $6,81 \pm 3,89$ & $6,83 \pm 4,18$ & $8,52 \pm 3,96$ & 0,020 & $7,36 \pm 4,04$ \\
\hline & $\mathrm{n}(\%)$ & $\mathrm{n}(\%)$ & $\mathrm{n}(\%)$ & & $\mathrm{n}(\%)$ \\
\hline Income & & & & 0,259 & \\
\hline $\mathrm{B}$ & $6(9,2)$ & $0(0)$ & $1(2,7)$ & & $7(4,7)$ \\
\hline $\mathrm{C}$ & $6(9,2)$ & $5(10,4)$ & $5(13,5)$ & & $16(10,7)$ \\
\hline $\mathrm{D}$ & $34(52,3)$ & $23(47,9)$ & $16(43,2)$ & & $73(48,7)$ \\
\hline $\mathrm{E}$ & $19(29,2)$ & $20(41,7)$ & $15(40,5)$ & & $54(36)$ \\
\hline Race & & & & 0,251 & \\
\hline White & $53(81,5)$ & $38(79,2)$ & $25(67,6)$ & & $116(77,3)$ \\
\hline Not White & $12(18,5)$ & $10(20,8)$ & $12(32,4)$ & & $34(22,7)$ \\
\hline Marital Status & & & & 0,059 & \\
\hline Single & $7(10,8)$ & $7(14,6)$ & $12(32,4)$ & & $26(17,3)$ \\
\hline Married & $42(64,6)$ & $33(68,8)$ & $18(48,6)$ & & $93(62)$ \\
\hline Widow/Divorced & $16(24,6)$ & $8(16,7)$ & $7(18,9)$ & & $31(20,7)$ \\
\hline Occupation & & & & 0,219 & \\
\hline Internal work & $29(44,6)$ & $26(54,2)$ & $23(62,2)$ & & $78(52)$ \\
\hline External work & $36(55,4)$ & $22(45,8)$ & $14(37,8)$ & & $72(48)$ \\
\hline Smoking & & & & 0,338 & \\
\hline Never smoked & $42(64,6)$ & $33(68,8)$ & $29(78,4)$ & & $104(69,3)$ \\
\hline Smoker & $3(4,6)$ & $5(10,4)$ & $2(5,4)$ & & $10(6,7)$ \\
\hline Ex-smoker & $20(30,8)$ & $10(20,8)$ & $6(16,2)$ & & $36(24)$ \\
\hline
\end{tabular}

$* *$ chi-square $* * *$ kruskal-wallis

Table 2 - Clinical characteristics according to the classification of adherence to the recommendations of the WCRF/AICR, of survivors of breast cancer in adjuvant hormone therapy, Santa Maria, RS, 2017.

\begin{tabular}{|c|c|c|c|c|c|}
\hline \multicolumn{6}{|c|}{ Adherence score } \\
\hline Variables & $0-4$ & $>4-5$ & $>5$ & \multirow{3}{*}{$\mathbf{p}$} & Total \\
\hline \multirow[t]{2}{*}{ n (\%) } & $\mathrm{N}=65$ & $\mathrm{~N}=48$ & $\mathrm{~N}=37$ & & \\
\hline & mean \pm DP & mean $\pm \mathrm{DP}$ & mean $\pm \mathrm{DP}$ & & mean \pm DP \\
\hline $\mathrm{BC}$ diagnosis (months) & $36,89 \pm 21,92$ & $36,50 \pm 16,98$ & $42,16 \pm 22,41$ & 0,416 & $38,06 \pm 20,06$ \\
\hline \multirow[t]{2}{*}{ HT treatment (months) } & $28,98 \pm 22,38$ & $25,37 \pm 16,90$ & $33,16 \pm 22,70$ & 0,376 & $28,86 \pm 20,93$ \\
\hline & n $(\%)$ & $\mathrm{n}(\%)$ & n $(\%)$ & & n $(\%)$ \\
\hline Type of HT & & & & 0,133 & \\
\hline Tamoxifen & $63(96,9)$ & $44(91,7)$ & $37(100)$ & & $144(96)$ \\
\hline Aromatase Inhibitor & $2(3,1)$ & $4(8,3)$ & $0(0)$ & & $6(4)$ \\
\hline Type of surgery & & & & 0,561 & \\
\hline Did not undergo & $2(3,1)$ & $0(0)$ & $2(5,4)$ & & $4(2,6)$ \\
\hline Not conservative & $31(47,7)$ & $23(47,9)$ & $15(40,5)$ & & $76(50,7)$ \\
\hline Conservative & $32(49,2)$ & $25(52,1)$ & $20(54,1)$ & & $70(40,7)$ \\
\hline Stage* & & & & 0,226 & \\
\hline $\mathrm{I} / \mathrm{II}$ & $56(86,2)$ & $37(78,7)$ & $26(72,2)$ & & $119(80,4)$ \\
\hline III/IV & $9(13,8)$ & $10(21,3)$ & $10(27,7)$ & & $29(19,6)$ \\
\hline
\end{tabular}




\begin{tabular}{|c|c|c|c|c|c|}
\hline Chemotherapy & & & & 0,906 & \\
\hline Yes & $36(55,4)$ & $29(60,4)$ & $21(56,8)$ & & $85(56,7)$ \\
\hline No & $29(44,6)$ & $19(39,6)$ & $16(43,2)$ & & $64(42,7)$ \\
\hline Radiotherapy & & & & 0,888 & \\
\hline Yes & $42(64,6)$ & $33(68,8)$ & $24(64,9)$ & & $99(66)$ \\
\hline No & $23(35,4)$ & $15(31,3)$ & $13(35,1)$ & & $51(34)$ \\
\hline Menopause status & & & & 0,816 & \\
\hline Natural & $50(76,9)$ & $39(81,3)$ & $30(81,1)$ & & $119(79,3)$ \\
\hline Induced/Not & $15(23,1)$ & $9(18,8)$ & $7(18,9)$ & & $31(20,7)$ \\
\hline Associated Diseases & & & & 0,287 & \\
\hline$\leq 1$ disease & $43(66,2)$ & $37(77,1)$ & $23(62,2)$ & & $103(68,7)$ \\
\hline$\geq 2$ diseases & $22(33,8)$ & $11(22,9)$ & $14(37,8)$ & & $47(31,3)$ \\
\hline
\end{tabular}

BC: Breast Cancer; HT: Hormone Therapy* no information from two patients** chi-square ***kruskal-wallis

Adherence to individual recommendations is presented in table 3. The individual recommendation with the highest level of adherence was the limitation of alcoholic beverages (76,7\%). In the worst adherence result $70 \%$ of the women did not practice physical activity.

Table 3 - Operationalisation of recommendations of the WCRF/AICR, 2018 and adherence to individual recommendations of breast cancer survivors in adjuvant hormone therapy, Santa Maria, RS, 2017.

\begin{tabular}{|c|c|c|c|}
\hline Recommendations & Categorization & Score & n (\%) \\
\hline \multirow{4}{*}{ Body weight } & \multicolumn{3}{|c|}{ Body weight $\left(\mathrm{kg} / \mathrm{m}^{2}\right)$} \\
\hline & $<24,9$ & 1 & $32(21,3)$ \\
\hline & $25-29,9$ & 0,5 & $67(44,7)$ \\
\hline & $>30$ & 0 & $51(34)$ \\
\hline \multirow{4}{*}{ Physical activity } & \multicolumn{3}{|c|}{ Physical activity (min/week) } \\
\hline & $\geq 150$ & 1 & $30(20)$ \\
\hline & $\geq 75-<150$ & 0,5 & $15(10)$ \\
\hline & $<60$ & 0 & $105(70)$ \\
\hline \multirow{8}{*}{$\begin{array}{l}\text { Eat a diet rich in whole grains, } \\
\text { vegetables, fruits and beans }\end{array}$} & \multicolumn{3}{|c|}{ vegetables(g/day) } \\
\hline & $\geq 400$ & 1 & $46(30,7)$ \\
\hline & $200-<400$ & 0,5 & $58(38,6)$ \\
\hline & $\leq 200$ & 0 & $46(30,7)$ \\
\hline & \multicolumn{3}{|c|}{ Fibers(g/day) } \\
\hline & $\geq 30$ & 1 & $19(12,7)$ \\
\hline & 15 a 30 & 0,5 & $69(46)$ \\
\hline & $<15$ & 0 & $62(41,3)$ \\
\hline \multirow{4}{*}{$\begin{array}{l}\text { Limit consumption of "fast } \\
\text { foods" and processed foods }\end{array}$} & \multicolumn{3}{|c|}{ Energy Density (Kcal/100g/day) } \\
\hline & $\leq 125$ & 1 & $94(62,7)$ \\
\hline & $>125 \mathrm{a}<175$ & 0,5 & $52(34,7)$ \\
\hline & $>175$ & 0 & $4(2,6)$ \\
\hline \multirow{4}{*}{$\begin{array}{l}\text { Limit consumption of red and } \\
\text { processed meat }\end{array}$} & \multicolumn{3}{|c|}{ Red meat (g/week) } \\
\hline & $<500$ & 1 & $65(43,3)$ \\
\hline & $\geq 500$ a 750 & 0,5 & $32(21,4)$ \\
\hline & $>750$ & 0 & $53(35,3)$ \\
\hline
\end{tabular}




\begin{tabular}{lccc} 
& \multicolumn{3}{c}{ Sugary drinks (g/day) } \\
Restriction of consumption of & 0 & 1 & $68(45,4)$ \\
sugary drinks. & $0<250$ & 0,5 & $74(49,3)$ \\
& $>250$ & 0 & $8(5,3)$ \\
Limit consumption of alcoholic & Never & Alcoholic beverages \\
beverages & Occasionally & 1 & $115(76,7)$ \\
& Weekly/daily & 0,5 & $29(19,3)$ \\
Dietary supplements & \multicolumn{3}{c}{ Not operationalized } \\
\hline
\end{tabular}

\section{DISCUSSION}

This study evaluated adherence to lifestyle recommendations from the WCRF, AICR 2018, in BC survivors. The majority of survivors had a general adherence score of less than or equal to four points. Participants with higher scores had a longer period of schooling. In the individual recommendations, physical activity and fiber consumption had the lowest adherence, and alcohol consumption showed the highest adherence.

The general score found was low, corroborating with that found in other populations of BC survivors. In the study of Inoue-choi et al (2013) with elderly survivors of the disease, in a total of 7 points, the sample mean was $4.0 \pm 1.2$. Higher adherence was significantly associated with better quality of life scores in physical and mental components. In other studies that also correlated quality of life with adherence to the recommendations of the WCRF/AICR, lower adherence was associated with worse sympto MW scale, in stages II or III (SONG et el., (2015). The study by Nomura et al (2016) evaluated the relationship between the incidence of BC and the general adherence score. The mean score was 5.0 points (range: 0.5 to 8.0 ). Women who adhered to six or more recommendations had the lowest risk of BC. Survivors who reported higher (6-8 points) versus lower (0-4 points) adherence to the WCRF/AICR guidelines had a lower risk of death (INOUE-CHOI; ROBIEN; LAZOVICH, 2013).

In this study, higher adherence was associated with participants with longer period of schooling. In the Brazilian population, individuals with lower schooling are susceptible to misconceptions about diet and nutrition, in addition to being more likely to practice less physical activity when compared to the ones with higher schooling (MOURA, MASQUIO, 2014; NUNES et al., 2015). Women who survived cancer and who have had higher adherence to the recommendations usually have a higher level of education, fewer comorbidities and a lower prevalence of current smoking (INOUE-CHOI; ROBIEN; LAZOVICH, 2013; INOUE-CHOI et al., 2013). In addition to higher schooling and no smoking history, older age was also associated with higher adherence scores (NOMURA et al., 2016). The characteristics of the cancer in our study did not differ regarding the levels of adherence to the recommendations either. In Inoue-choi et al., the stage of the cancer, previous therapies and current treatment for the disease did not differ between the levels of adherence. 
Assessing adherence to individual guidelines is of great importance since certain recommendations have a stronger impact on the risk of câncer (MAKAREN et al., 2015). Findings are still limited in relation to outcomes, including prognosis and quality of life after treatment (WCRF/AICR, 2018). In BC survivors, possible risk-reducing behaviors are associated with physical activity, consumption of foods containing fiber and soy, and increased risk associated with body fat and saturated fat consumption (WCRF/AICR, 2018). As to the recommendations of 2018, there was an increase in the consumption of fibers from $25 \mathrm{~g}$ to $30 \mathrm{~g}$ when compared to the ones of 2017 and the sodium intake recommendations were removed (FANIDI et al., 2015; WCRF/AICR, 2018).

This study corroborates with the results of Hastert et al., in which more than $70 \%$ of the women meet the recommendation to limit alcohol consumption. In this study, the risk of developing $\mathrm{BC}$ was $49 \%$ lower for scores on the alcohol component. Along with the body weight recommendation, alcohol is associated with a lower incidence of this cancer. Low alcohol consumption and plant-based diets are associated with the lower risk of BC and other cancers (MAKAREM et al., 2015).

In other populations with cancer, as in this one, less than $40 \%$ meets the body weight and physical activity recommendations (HASTERT et al., 2013). The risk of BC is lower in women whose BMI is in the normal range and who do physical activity (INOUE-CHOI; ROBIEN; LAZOVICH, 2013; HASTERT et al., 2013). BC survivors who present lower BMI and higher physical activity levels have a better overall quality of life (SONG et al., 2015). Staying physically active is the most important factor in health behavior to prolong life after cancer diagnosis among women and decrease the risk of recurrence (CHLEBOWSKI, 2013; INOUE-CHOI; ROBIEN; LAZOVICH, 2013). Cancer therapies have significant side effects that may, in the long run, increase morbidity and worsen survival. Allying non-pharmacological methods to treatment, such as healthy eating and physical activity emerges as the most practical option currently available, to reduce the impact of the disease and improve quality of life (IRWIN, MAYNE, 2008).

This study presented the limitation of collection in a single moment, which made it difficult to establish if the prevalence of adherence is temporal. Sampling, from one reference center, may not be representative of the entire population, as well as the lack of a control group for comparison. Despite this, this study could identify risk groups and guide health action and planning, since overall adherence to the recommendations of the WCRF/AICR was low. The data suggest that Brazilian breast cancer survivors, especially those with lower levels of education, could benefit from dietary counseling and, above all, physical activity. Studies that better establish relationships of weight, physical activity and diet and the impact of interventions on improving quality of life and reducing mortality, and the association between sociodemographic and clinical factors and these habits are still necessary. 


\section{REFERENCES}

AICR. Cancer survivors. 2018. Available at: https://bit.ly/3Elwa0H. Acessed: May, 01, 2018.

CHLEBOWSKI, RT. Nutrition and physical activity influence on breast cancer incidence and outcome. Breast, v. 22, n. 1, p. 30-37, 2013.

DE MOURA, A.F.; MASQUIO, D.C.L. A influência da escolaridade na percepção sobre alimentos considerados saudáveis. Revista de Educação Popular. v. 13, n. 1, p. 82-94, 2014.

FANIDI, A. et al. Adherence to the World Cancer Research Fund/American Institute for Cancer Research câncer prevention recommendations and breast câncer risk in the Cancer de Mama (CAMA) study. Public Health Nutrition, v. 18, n. 1, p. 3337-3348. 2015.

FERRINI, K.; GHELFI, F.; MANNUCCI, R. Lifestyle, nutrition and breast câncer: facts and presumptions for consideration. Ecancer medical Science, v. 9, n. 1, p. 449:557, 2015.

HASTERT, T.A. et al. Adherence to WCRF/AICR cancer prevention recommendations and risk of post-menopausal breast cancer. Cancer Epidemiology Biomarkers e Prevention, v. 22, n. 1, p. 14981508, 2013.

INOUE-CHOI, M.; ROBIEN, K.; LAZOVICH, D. Adherence to the WCRF/AICR guidelines for cancer prevention is associated with lower mortality among older female câncer survivors. Cancer Epidemiology Biomarkers e Prevention. v. 22, n. 1, p. 792-802, 2013.

INOUE-CHOI, M.; et al. Adherence to the World Cancer Research Fund/American Institute for Cancer Research recommendations for cancer prevention is associated with better health-related quality of life among elderly female cancer survivors. Journal of Clinical Oncology, v. 31, n. 1, p. 1758-1766, 2013.

IRWIN, M.L.; MAYNE, S.T. Impact of nutrition and exercise on cancer survival. Cancer Journal, v. 14, n. 1, p. 435-441, 2008.

MAKAREM, N. et al. Concordance with World Cancer Research Fund/American Institute for Cancer Research (WCRF/AICR) guidelines for cancer prevention and obesity-related cancer risk in the Framingham Offspring cohort (1991-2008). Cancer Causes Control. v. 26, n. 1, p. 277-286, 2015. 
NOMURA, S.J. et al. WCRF/AICR recommendation adherence and breast cancer incidence among postmenopausal women with and without non-modifiable risk factors. International Journal of Cancer, v. 138, n. 1, p. 2602-2615, 2016.

NUNES, A.P. et al. Domínios de atividade física e escolaridade em São Paulo, Brasil: estudo transversal seriado, 2003 e 2008. Caderno de Saúde Pública, v. 31, n. 1, p. 1743-1755, 2015.

RIBEIRO, A.C.; OLIVEIRA, K.; RODRIGUES, M.D.L. Validação de um questionário frequência de consumo alimentar para população adulta. Revista de Nutrição. v. 19, n. 1, p. 553-562, 2006.

ROMAGUERA, D. et al. Is concordance with World Cancer Research Fund/American Institute for Cancer Research guidelines for cancer prevention related to subsequent risk of cancer? Results from the EPIC study. The American Journal of Clinical Nutrition, v. 96, n. 1, p. 150-163, 2012.

SONG, S. et al. Adherence to guidelines for cancer survivors and health-related quality of life among Korean breast cancer survivors. Nutrients, v. 7, n. 1, p. 10307-10319, 2015.

WHO. Physical status: the use and interpretation of anthropometry. Geneva: WHO technical report series; $1995.854 \mathrm{p}$.

WCRF/AICR. Energy balance and body fatness. Continuous Update Project Expert Report, Inc; 2018. Available at: https://bit.ly/2XBCQYB. Acessed: June, 03, 2018.

WCRF/AICR. Food, Nutrition, Physical Activity, and the Prevention of Cancer: a Global Perspective. Washington DC: AICR, Inc; 2007. Available at: https://bit.ly/3b3v6lb. Acessed: April, 10, 2018.

WCRF/AICR. Diet, Nutrition, Physical Activity and Cancer: a Global Perspective. Continuous Update Project Expert Report, Inc; 2018. Available at: https://bit.ly/3B59dN5. Acessed: June, 02, 2018.

WCRF/AICR. Survivors of breast and other cancers. Continuous Update Project Expert Report, Inc; 2018. Available at: https://bit.ly/3nhRFZ5. Acessed: June, 02, 2018. 